\title{
Body, Language and Sexuality in Oh les beaux jours
}

\section{Marzia CAPORALE}

$\mathrm{U}$

T $\mathrm{p}$ until the late 1950's, Beckett's plays do not display a great interest in gender issues and male/female relationships. Too concerned with showing the misery of the human condition, his theater is filled for the most part with characters who are ill, old, paralyzed, physically incapable of moving and/or mentally unable to produce coherent thoughts. From this perspective, Oh les beaux jours represents a step in a new direction. Not only is the protagonist, Winnie, a female when all the main characters until now, in theater and fiction, had been male; ${ }^{1}$ she is also a feminine character who in her monologues brings up issues of female sexuality and desire, thus placing the female body at the center of the play. The roles of the characters, their gender, are not in the least interchangeable. Winnie is a woman and approaches life and its absurdity from a completely feminine perspective: from the desire to be admired by the other sex to the refusal of motherhood, her character deals with problems that pertain specifically to women. By making the protagonist a seemingly still attractive woman who is still aware of her sensuality and does not want to simply await death, Beckett temporarily shifts the focus of his writing from a general metaphysical interrogation of the meaning of existence for all mankind to a more specific exploration of the dynamics of female (and male) bodies, their desires and the (im)possibility to realize them. 
Winnie, a woman in her fifties, is trapped in a mound of dirt, she is obviously menopausal, and cannot create life. In spite of that, she will find alternative ways to not give in to death and will fight to find meaning even where there seems to be none. As her body disappears and is buried in the ground from act one to act two, she hangs on to language as the only way to affirm her identity as a woman and as a character. The logos while problematized, torn apart, deprived of its referential coordinates, still remains a powerful tool to get through the day and create a presence in a desert where absence is the only dominating principle.

The first mark of such absence, other than the barren decor, is the body itself, and the female one in particular. As Katherine M. Gray rightly observes, Beckett's theater over the years tries to do away with the traditional notion of character, stripping the body down to its bare essentials and sometimes eliminating the body from the stage, leaving only parts of it and thus nullifying the notion of a unified subject. The physical as well as the psychological elements that make up a character are gradually reduced so that in the late theater characters signify more by what is not shown than by what the spectator can see. When compared to the characters of later plays who are either just voices without bodies or nameless sexless beings, Winnie can still be considered somewhat "traditional." Gray defines Winnie as a "factic" body which still "operates within the familiar conventions of western representation" (4). She acts and speaks according to the cultural and social model in which she is inscribed. She does not belong to an abstract world which has no connection with reality. She behaves and performs as should be expected from a woman and a wife in her fifties who still wants to look attractive to others while at the same time is in an unsatisfying marriage.

The apparently mimetic nature of the play is, however, quickly undermined by the grotesque situation the characters find themselves in. The couple on stage are indeed husband and wife and the play portrays the banalities of married life. Winnie apparently fits the stereotype of the petulant wife who talks without pause about all sorts of unimportant events while Willie plays the role of the bored and distracted husband who ignores her and keeps reading the newspaper or sleeping, barely responding to her monologues. At the beginning of act one, while Winnie is buried up to her waist in a mound of dirt, Willie is behind her, half hidden from view, and asleep. The place where they live is unidentifiable except for the fact that it is obviously a desert, since nothing grows there and all one can see is an "étendue d'herbe brûlée," "un ciel sans nuages" 
and "une plaine denudée" (11). Everything in the decor suggests images of void and absence of life.

Winnie, who is the main voice on stage, nevertheless stands in open contrast to the hostile environment that surrounds her. As I stated earlier, she is the incarnation of femininity itself. Her physical appearance, her purse, her props, her gestures: everything points to a woman who is conscious of her sexuality and is proud of her body. Unlike most Beckettian characters, she is neither old nor dying. Winnie is indeed immobilized in the mound that hides her up to the waist, and in this sense she is no different from more conventional characters like those in Fin de partie who are stuck in garbage bins or confined to a wheelchair; however, she is not ill nor seemingly anywhere near approaching death. On the contrary, her physical description at the opening of the play states that she is a sensual woman, in spite of her not so young age: "blonde, grassouillette, bras et épaules nus, corsage très decolleté, poitrine plantureuse" (11-12). Although the lower part of her body is buried in the ground, the upper part, which she can still show, creates the image of a woman who has not given up hope of being attractive. Winnie is always coquette: she puts on lipsticks, files her nails, looks at her image in the mirror. Her character, so full of life, is in open contrast with that of her husband who is passive and powerless. Willie has no "will" in spite of his name and has no sexual energy either, despite what the little pun with his name suggests in English ("willy").

The marriage between the two characters is clearly a failure. Winnie herself states that Willie is "bon qu'à dormir" (15). He barely speaks throughout the play, and passively sits by his wife, occasionally responding to her monologues by short fragments of sentences or by quotations from the newspaper he is reading. Apparently, he is unable to produce any original thought and translate it into language. Shari Benstock has remarked that Willie's failure to talk and communicate with Winnie and his hiding behind the mound suggests that he is subjugated: in her words, he "takes up the position the female has traditionally played in Western society - hidden, silent, called upon to attend" (180). Winnie, on the other hand, has her own voice and dominates the stage regardless of her immobility. Her language, which for the most part consists of memories of the beaux jours past, fills the void created by an absent body. During her long monologues, Winnie celebrates times far happier than the present, times when she was not trapped in the mound, when her husband was not reduced to an animal-like condition. In particular, Winnie relives the days of her youth, when her body was her main device for 
seduction, when she still had use of her legs, her sexual organs were not hidden from the eye, and her desires were still (theoretically) possible.

At present, Winnie's sexual energy is frustrated. Her desires, which still exist, (her sexual desire in particular), must find different means of expression. On the one hand, the props replace the desired object by becoming Winnie's focus and the center towards which she directs all her energy; on the other hand, her memory will help her rebuild her youth and relive the time when pleasure was not forbidden. The objects that come out of Winnie's purse are a continuation of herself. Metonymically, she turns her desire towards the contents of the purse and towards the props that surround her. She keeps going back to them, looking at them with great surprise every time she extracts them from the bag. Since her desire is trapped and has no way to realize itself, Winnie works by substitution: instead of giving in to an overwhelming sense of paralysis and failure, she diverts her attention elsewhere. The male/female relations which are impossible under the circumstances find a sort of correlated correspondence in the objects of the purse. The props are a mixture of typically feminine paraphernalia (the lipstick, the mirror etc) and phallic symbols: the umbrella, the toothbrush, the revolver - the symbol of a love which generates death instead of life.

The revolver is the only one among Winnie's props which clearly does not belong to the feminine universe: most of the objects she pulls out of her bag fit, more or less, the category of "toiletries" and are all indicators of that feminine coquetterie that is a mark of Winnie's character. As Alain Benoist observes, these objects (mirror, file, toothbrush) do not create a contrast with the "referential universe": on the contrary, they stem directly from it. In his words, "les objets tirés par Winnie de son sac sont liés entre eux par une référence calquée sur le réel, qu'on pourrait appeler la toilette du matin" (280). The revolver, however, does not fit in the same group and represents an instance of rupture with the "référence au réel." The revolver should not really be found among the other objects it is associated with. While Winnie's toiletries are representative of an all feminine world, the revolver introduces a typically masculine element, suggesting aggression, violence and death. Paradoxically, however, it is necessary because in Winnie's eyes it probably represents the exaggerated virile masculinity that is absent in her husband and which therefore complements her femininity. When she first extracts it from her purse, the stage direction tells us that Winnie "lui donne un baiser rapide" (18), an action apparently incongruent with the type of object she is holding but perfectly coherent with the symbolic function of the revolver as the 
replacement for her husband, a surrogate of the partner she does not have. It is not by accident that when all the other props disappear and her body is all buried in the mound, the revolver still remains by her side.

In act two, when Winnie is buried up to her neck in the ground and no longer has use of her arms, the lipstick, the nail file and the mirror lose all purpose. Since Winnie does not have use of her hands, they have no reason to appear on stage anymore. The revolver, however, remains, the faithful companion to Winnie's solitude, signifying not by its immediate meaning (a lethal weapon is fairly useless if no one is going to pull the trigger) but by what it represents symbolically. In fact, even though the most evident reason for its presence would probably be to suggest the idea of Winnie's suicide, such an idea would be impossible to put into practice since Winnie's arms are buried and Willie does not seem capable of such drastic measures. Also, suicide for Beckett and his characters is not an answer to the absurdity of life: Winnie in particular wants to keep living and making it through the day in the best way possible and fights every moment to ensure that her life has some sort of meaning. Rather, the revolver's status as phallic symbol indicates that in Winnie's eyes it replaces the masculine features her husband no longer posseses.

In order for Winnie to keep talking about her femininity there has to be another term in the equation. It would be fairly useless to hang on to the terms of her womanhood if there is no male element to listen and counterbalance. While Willie is technically her auditor, he has lost all marks of virility. When Willie climbs Winnie's mound at the end of the play, she is not sure whether he is trying to reach her or the revolver: "C'est moi que tu vises, Willie, ou c'est autre chose?" (75). Either way, his attempt can only fail. This mock representation of sexual intercourse can never work if the phallic symbol is not a part of the husband's body anymore, but lays on the ground, completely detached from it. So in the end, while both characters have lost the parts of their bodies that made them men and women respectively, only one of them, Willie, has also lost his "self." By being silent, by giving up language, he can find no alternative to the deterioration and disappearance of the body and is the ultimate failure. Winnie, on the other hand, never gives up believing in words as the only possible makers of meaning in a world that has lost everything else.

Winnie's speech constantly goes back to past loves and is filled with sexual references, to her own sexuality as well as other people's. Clearly, the issue of sexuality is cause for an internal conflict. While Winnie's body is still attractive, the mound hides it, immobilizes it and prevents her 
from having any physical contact with Willie or with any other male, if there was ever one in this desert. The image of the mound that entraps Winnie becomes more and more tragic as the play moves from the first to the second act. Winnie undergoes a radical transformation: she will eventually become one with the earth. The double meaning of the word mamelon in French suggests not only that Winnie is going to be swallowed by the mound, but also that she is going to metamorphosise herself into the very thing that the mamelon seems to represent here: a female breast. The situation is paradoxical: this mamelon which is the emblem of female sexuality denies Winnie the possibility of living her own sexuality by keeping her prisoner. Most importantly, the mound blocks all access to the sexual organs which are invisible and therefore (in theatrical terms) non-existent.

In any event, even if Winnie were free to walk around and her organs were not buried in the ground, the search for pleasure would still most likely fail. In the first act, the upper part of Winnie's body is still visible and she is well aware of the fact that her poitrine still holds some seductive power. Yet Willie is not capable in his role as a husband and the place where they live is deserted. Nobody can appreciate what is left of her sensuality. In fact, throughout the play Winnie is obsessed with her breasts and with the fear of not being able to seduce. Even if the absurdity of her condition makes it impossible for her to actively look for ways to realize her sexual desire, she never gives up her femininity. She wants to know that her body, at least during a happier past, had the power to attract the male gaze. For this reason she asks Willie: "Fut-il un temps, Willie où je pouvais séduire? (Un temps.) Fut-il jamais un temps où je pouvais séduire?" (38) But Willie does not know how to answer.

Winnie is aware that, once the earth has covered her body, the part of her body that is hidden from the eye will not exist anymore. Her monologues show an increasing preoccupation with this inevitable disappearance: "Et si un jour la terre devait recouvrir mes seins, alors je n'aurais jamais vu mes seins, personne jamais vu mes seins" (46). Her fear soon becomes a reality. At the beginning of the second act, her breasts have indeed disappeared, creating another absence. All the signs of Winnie's sexuality have been hidden. Even her hands are buried so she cannot play her typically feminine games of putting on the hat, the lipstick and toying with the mirror.

Following the same process of disintegration of the body, the language becomes more and more fragmented. Winnie's commentary on her condition during the second act does not contain a verb. She names 
the parts of the body as if, by saying them out loud she could recreate them: "Mes bras. (Un temps.) Mes seins. (Un temps.) Quels bras? (Un temps.) Quels seins?" (61). The sentence shifts from an affirmative to an interrogative mode. Since the arms and the breasts are no longer visible, she begins to doubt that they ever existed. The only way to recreate them is through memories; for this reason, she evokes the words of the last people that passed through this desert and admired her: "Pas mal la poitrine, dit-il, j'ai vu pis. (Un temps.) Pas mal les epaules, dit-il, j'ai vu pires" (70). The couple in question displays a sexual curiosity towards Winnie and her bizarre situation. After having commented on her breasts and shoulders, the male of the couple, a so called Mr. Piper, or Cooker as Winnie recalls, wonders if Winnie is naked inside the mound ("Est-ce qu'elle est à poil là-dedans?" [70]). Although the comments are indiscrete and although the couple sees woman as an object more than as a human being (they never address her directly but talk about her in the third person), Winnie recounts the anecdote with a certain degree of pleasure because it was a moment when someone other than Willie, looked her and her body and commented on it. Also the couple is a projection of what her own life could be like if she were not trapped in the mound: a mixture of clichéd romantic moments (the couple holding hands "main dans la main," which she repeats twice) and distorted sexual curiosity.

The awareness of the bareness of the present and of the impossibility of fulfilling her desires and of having full control of her body increases the conflict between Winnie and her own sexuality: now that all her reproductive organs are buried and useless, she finds other people's sexual pleasure an outrage. The postcard that Willie shows her is a clear indication of this conflict: "Non, mais c'est de la veritable pure ordure! (Elle examine la carte) -De quoi faire vomir - (Elle examine la carte) Tout être qui se respecte" (24). Clearly the postcard portrays individuals engaging in sexual relations. Winnie's reaction at what she sees is exaggerated and contradictory: she is fascinated and disgusted at the same time. Her words and her gestures do not coincide, thus creating a comical moment: she says that what she sees is disgusting and yet she examines it closely to better see the details of the scene. Her body and her language therefore operate on two separate levels.

It is clear from what Winnie remembers about her own sexual life that her desire never found fulfillment even during the beaux jours she keeps talking about. In particular, her relationship with Willie from this point of view is evoked with a tone of deep melancholy which is normally not associated with positive memories of past love experiences: "la tristesse 
au sortir des rapports sexuels, celle-la nous est familière, certes" (69). Even the evocation of a typically happy time like her wedding day is marked by sadness and bitter tones: "Ce jour-là (Un temps.) Le champagne rose (Un temps) Les verres flûtes. (Un temps) Enfin seuls. La dernière rasade, les corps se touchant presque. Le regard (Un temps long). Quel jour-là? Quel regard?" (72). Winnie moves from traditionally romantic images to potentially sexual images of the newlyweds finally alone after the ceremony, but the climax of the scene is abruptly cut by the last two questions: as the question marks suggests, perhaps this day of happiness and Willie's longing gaze never existed. The episodes which should have represented the culminating moments of love and passion were apparently just a utopia or a creation of her own mind.

All sexual references in the play acquire a negative connotation. The seemingly innocent anecdote of Mildred and the mouse running up her thigh that Winnie recounts in act two continues the idea of the pure ordure of act one and at the same time suggests the somewhat shocking image of a rape. The mouse climbing up Mildred's leg causes the little girl to start screaming and let go of her doll. When the parents run to the scene to see what had caused such a stir, Winnie comments "Trop tard [... trop tard" (71). Her words are ambiguous and are decontextualized because we have not been told what they arrived too late for: maybe it was too late simply to keep the girl from screaming and being terrified by a silly accident, or maybe too late to prevent a sort of mock sexual violation. That the story has sexual undertones is made clear by the fact that Winnie is bothered by it, so much that she feels she must change the subject abruptly and drop the disturbing memory of Mildred and her mishap with the mouse. In fact, Winnie had already tried telling this same story earlier but had had to stop at the crucial moment when the mouse had started climbing up Mildred's leg. She recalls that Milly "entra dans la nursery et se mit à deshabiller Fifille. (Un temps). S'enfila sous la table et se mit à deshabiller Fifille (Un temps). La grondant cependant. (Un temps) Soudain, une souris - (Un temps long)" (67). The climactic moment is postponed until a few minutes later when Winnie goes back to the scene just as she had gone back to look at the postcard over and over. In her eyes, these examples of "distorted" sexuality are disturbing and fascinating at the same time. After all a dysfunctional kind of sexuality is all Winnie has ever known, even when she was free from the ground: being buried up to her neck is not necessarily a horrible punishment from her point of view: while it keeps her sexual organs inactive, it also protects them from undesired attacks like that of the mouse in Mildred's story. 
Winnie's entrapment in the ground, her sexual paralysis and consequent sterility do not undermine her sense of femininity but do prevent any possible connection between Winnie and motherhood. In fact, by placing the female protagonist in a mound of dirt that blocks all access to her organs and greatly limits her freedom of movement, Beckett reverses traditional feminine myths. The mound where she lives is a part of the earth, of the terra mater. Traditionally, mother earth is fertile and generates life as does the woman's uterus. However, if the earth is not fertile, Winnie will not be either. In spite of her strong sensuality, Winnie, although somewhat maternal towards Willie at times, is not a mother figure: after all, her uterus is buried with her other organs and cannot be accessed and cannot function. For her however, this sterile condition is not necessarily a curse. On the contrary, after noticing that the ground around her does not produce any sign of life she remarks: "Quelle bénédiction que rien ne pousse, imagine toi si toute cette saloperie se remettai à pousser" (41). The grass is burned and there is no hope that life will ever come out of this place. The mother earth has become rather like the evil step-mother. It holds Winnie prisoner and does not allow the cycle of life to continue. In this respect, her position is not very different from other Beckettian characters who associate the moment of birth with death and who curse their parents for bringing them into this world. Hamm in Fin de partie cannot forgive his father for having generated him and accuses him openly, as if giving life was a crime: "Salopard, pourquoi m'as tu fait?" (69); "maudit progeniteur" (24); "maudit fornicateur" (25). Parenthood is seen as the ultimate sin as it can only give way to pain. Winnie's idea that sterility is a blessing is nonetheless new in Beckett's theater because this time it is a woman who rejects the traditional notion of motherhood as a blessed event and of birth as a new joyful beginning. Winnie goes not only against her nature but also against societal constructs which want a woman to be first of all a wife and a mother: she wants to be a woman but not a mother, since she is well aware that there is no possibility for life to be born here and even if it were, it would only cause more misery. ${ }^{2}$

Inevitably, the few episodes during the play which may suggest the possibility of a (re)birth prove themselves to be illusory. Winnie who is worried that Willie is spending too much time under the hot sun. encourages him to go back in his "trou." This image could be read as a sort of regressio ad uterum: the hole in this case would be the mother's vagina, where Willie should go to (possibly) be reborn. ${ }^{3}$ At the same time, Willie's somewhat animal nature which makes him creep like a reptile or 
walk on all fours like a dog suggests that the hole Winnie is referring to is also a burrow where he can go hide when he wants. In any event, whether we see him as a "baby" or as an "animal," by going back to the hole Willie proves that he is not able to satisfy Winnie's desires. He is unable to pronounce the word "fornication" as if it were a taboo. The little pun created by the mix-up between fornication and "formication" set in motion by the arrival of an ant creates the other image which could theoretically evoke the idea of motherhood and birth. The ant, which is one of the rare living creatures to have passed through this desert, resembles a mother carrying a baby, as Winnie observes, "Elle a comme une petite balle blanche dans les bras" (36). But again, this is nothing other than illusory. Although it looks like a mother, it is not a mother and birth proves once again to be an impossible task here.

Clearly, in a desert sterility is the norm. Paradoxically though, the mound where Winnie is buried, in its function as mamelon or breast of the mother earth should be able to generate life and it does so in a way. The main function of a mother's breasts is in fact to give life to the newborn babies through the milk they produce. Here, the only flow that comes out of the mamelon is represented by Winnie's words. One can say that Winnie's outpouring of language does create life, much like the above mentioned milk. Of course, it is a "life" that has many limitations. Her words are not linear but rather circular, made of repetitions, returns, déjà vus. In other words, language and time follow a similar pattern and are equally detached from the physical world the characters live in. Time has also lost its linear progression: tomorrow is going to be a re-enactment of today, more anecdotes, more questions that will not be answered. Many times, Winnie's language is rooted in the past and is made up of fragments of memories. The present after all does not offer her much to talk about and past memories are the only weapon Winnie has to fill the emptiness of her days.

Winnie spends the final moments of the play alone with her memories and monologues while Willie, who remains silently by her side, seems to have lost the power even to respond with the monosyllabic phrases of the first act. The play ends with the failed attempt on Willie's part to climb Winnie's mound, the mons veneris according to Kristin Morrison (30). His last effort to touch his wife and supposedly attempt the sexual act can only have one possible ending. Winnie, however, notices her husband's painful efforts and tries to encourage him. "Il fut une époque où j'aurais pu te donner un coup de main (Un temps). Et une autre, avant, où je te donnais un coup de main. Tu avais toujours bougrement besoin 
d'un coup de main [. . . Essaie encore une fois, Willie, je t' acclamerai" (7576).

Evidently, Willie has never been able to satisfy Winnie's desire. At present, both members of the couple are unable to have sexual relations. Winnie has become as powerless as her husband. Her hands, her body do not exist anymore. Her desire remains an impossible task to realize.

Willie's last word after his final failure is "win." His language is never very articulate and his remarks, as Martine Antle observes, are often just repetitions of pieces of Winnie's phrases (564). Here, Willie cannot pronounce his wife's name in full. He can only utter a fragment of it because Winnie herself is not whole anymore. Language only reproduces the process of dismemberment that the body is subject to. Ironically though, Willie's final word also suggests the idea of victory, but there is no victory for him. Willie has failed as a husband and as a human being. In the end, unable to satisfy neither his desire nor Winnie's, he is still on all fours like an animal or a baby who has not yet learned how to walk. He is defeated while Winnie is at least partially victorious. Willie's voice pronounces at least a portion of her name and for her that is proof that the world has not yet ended, that she is not left all alone. Even though she cannot see her husband, his voice confirms his presence which gives her reassurance.

While we can assume that Willie is sexually impotent throughout the play and has been for some time. Winnie, as I have discussed, is a sensual woman who must hide her body and repress her sexual drive. In a way, her desire still to look attractive to others makes her a part of that male oriented cultural model that Luce Irigaray wants to undermine when she says: "la femme jouit plus du toucher que du regard, et son entrée dans une économie scopique dominante signifie encore une assignation pour elle à la passivité: elle sera le bel objet à regarder" (25). In fact, Winnie does want to be seen and admired. Throughout her monologues, she worries more and more about the possibility of not being seen anymore, and of losing the marks of her femininity. However, in spite of her passivity which derives from being trapped in the mound, unable of moving or showing her body, she is not in a subordinate position. Her ability to speak and be the undisputed protagonist of the performance puts her in a position of power normally destined to the male. With regard to her relationship to Willie, she is the one in charge: she tells him what to do, she tries to control his actions. But most of all, she has la parole, something her husband does not have. 
Positioned at Winnie's feet, incapable of speaking as well as of performing his duties as a husband, Willie can only listen and watch. Winnie on the other hand overturns the traditional binary opposition which sees woman as "other" from man, relegated to a subordinate position and speaks to demonstrate that words and language are not dead. Her constant need to look in the mirror in the first act might suggest that Winnie subscribes to the cultural codes dictated by society for which a woman should always look attractive even under adverse circumstances: however, as Shari Benstock remarks, "Winnie does not consult her mirror for reassurance of her place in the signifying chain of patriarchal approval [. . .] The series of questions she poses the mirror suggests a need for understanding the mystery of her condition" (176). Her apparently futile gestures of looking in the mirror or putting on makeup are in reality her attempt to create meaning in her day, to fill a blank page which would remain tragically empty without her words and limited but important actions.

The disappearance of Winnie's body, her physical paralysis, her being stuck in a mound of dirt could be read metaphorically as implicit to the feminine condition in society and culture and could suggest that Winnie is a victim, incapable of escaping her constraints, unable to set herself free from an unfulfilling marriage. Helène Cixous defines the feminine condition in society as "decapitation" and argues. "Women have no choice other than to be decapitated, and in any case the moral is that if they don't actually lose their heads by the sword, they only keep them on on condition that they lose them - lose them that is, to complete silence, turned into automatons" (481). Winnie, however, escapes such definition because she never loses her head, both in the literal and the figurative sense. While the rest of her body progressively disappears, the head remains, and with it its ability to think and talk. Winnie is not silenced in the sense that Cixous intended. She speaks in order to continue living as a woman and as a character. As I have demonstrated, the play does not perpetuate a phallocentric view of the world in which the dominant cultural code sees woman as subject to the male power. Traditionally, in the husband-wife relationship, the husband is the term of priority: the male holds all the power. Here, on the contrary, while the play does not want to promote the superior role of women in society, it ultimately creates a clear reversal of the traditional roles by making Winnie the "winner" and Willie the loser. Winnie is one of the few characters in Beckett who manages to successfully fight the tragic situation she is in (at least from her perspective). She learns to make the most of what she 
has: words, language, memories, anecdotes - all of those to be used sparingly throughout the day, as she observes, because if she ran out of things to say she would be confronted with silence and an intolerable absence. The absence of the body she can deal with, but language must stay, in order for the performance and for life to go on.

Willie does, nonetheless, have a role in the context of the play. Winnie needs him as the spectator to her performance: without an audience, her monologues would be wasted, there would be nobody to listen to her and validate her existence following the Berkleyan axiom esse est percipi that is at the base of all of Beckett's plays. While Willie is incapable and useless as a husband, he fulfills the role of "auditor" fairly well. In fact, he is (almost) silent, as a spectator should be watching a play being performed. As Winnie exclaims: "Ah, si seulement je pouvais supporter d'être seule!" (26). But Winnie cannot stand being alone. Winnie acknowledges that her partner is good for nothing, spits on him after rinsing her mouth with the toothpaste (although perhaps accidentally, since her movements are limited) and throws the bottle of medicine behind the mound hitting Willie on the head and making him bleed. The scene is grotesquely comical, almost reminding the audience of certain devices of the commedia dell'arte where laughter is often derived from the characters beating each other - the famous coups de bâton - and from other forms of (mild) physical violence. Here Winnie takes on another role traditionally reserved for the male in unhappy marriages: that of the abuser. The husband is the abused in this case: regardless of the treatment he receives, he sits faithfully by his wife and does not complain. At the same time Winnie begs Willie to stay with her, to listen to her talk because his presence is not accessory but necessary: "Je t'en prie, mon cheri, sois gentil, ne te rendors pas. Je pourrais avoir besoin de toi" (18). As Carla Locatelli observes, the problem of self-identification is a central issue in Beckett's theater and Oh les beaux jours is no exception. She remarks that "self is established only as the object of a dialogical self-awareness [...]: the establishment of one's own identity is again shown to be dependent on a strategic communication between the self and the other, or between the self and the self as other" (125). Winnie's need to speak would be nullified if Willie was not there to listen. A speaker necessarily needs an auditor, or the whole act of speaking becomes futile.

Of course, no real communication takes place here, since the auditor is for the most part silent and unresponsive, but his presence is enough to keep Winnie's monologue going, to justify the utterance of her words. Often Winnie expresses her anguish at the idea that Willie might die or 
disappear and that she might be left without her audience, making her words useless. Speaking of his presence next to her, she admits: "C' est ce qui me permet de continuer, de continuer à parler, s'entend. Tandis que si tu venais à mourir [. . . ] ou à t'en aller en m'abandonnant, qu'est-ce que je ferais alors, que'est-ce que je pourrais bien faire toute la journée [...] simplement regarder devant moi, les lèvres rentrées. [. . .] Plus un mot jusqu'au dernier soupir, plus rien qui rompe le silence de ces lieux" (27). Although it appears at times that Winnie wishes to engage in some sort of dialogue with Willie, it is soon clear that communication as such between the two members of the couple is not possible and that Willie's words are often just a pretext for Winnie to start fantasizing about her own past and about her own love experiences that do not include her husband, thus reaching complete separation from him. A few words from a newspaper article that Willie reads aloud and contain the name Carolus Chassepot evoke in Winnie memories of a former lover named Charlot Chassepot, as she reminisces being "assise sur ses genoux" during the "beaux jours de bonheur" (21). And again, memories of past romances bring on more of the same. Through language, through fragments of her memories, Winnie is able to relive the times of her youth and happiness. Willie is not an interlocutor but merely a spectator, almost forced to the voyeuristic role of having to listen to his wife recount her past love experiences that do not involve him: "Mon premier bal! Mon second bal! Mon premier baiser [. . . Un kinési ou un mécanothérapeute. Demoulin ou Dumoulin ... voire Desmoulins, c'est encore possible. Moustache fauve très dure." (22) An example, the latter, of that stereotypical masculinity that Willie does not possess.

Winnie's quest to keep her "self" alive in spite of her solitude and in spite of the disappearance of her body must necessarily go through language as the only possible way to keep her identity from disappearing. Her speech has no choice but to revert back to the times when the body was whole, as a way to give meaning to the words she utters. It is useless to talk about her present situation when only pieces of her old self exist and her body has lost its unity: in M.C. Hubert's words, "la partie ne peut venir représenter un tout puisque l'unité n'est pas percue [. . . Le corps est donné à voir comme un mode existentiel. Le corps est béant, une brèche a été irrémédiablement ouverte. Al'image, manquera toujours un morceau" (208).

As Winnie herself acknowledges, to speak of her current situation and to name the different parts of her body that are buried under the mound is equivalent to saying a series of words that are empty and out of 
context. In order for the word "leg" or "breast" or other to produce meaning there must be a direct correspondence between the signifier and the referent. If the latter is absent from the picture, the whole notion of sign as unit of meaning will lose its value. Winnie's constant return to the past is an attempt to hold on to the referent and to restore the linguistic sign to its original communicative function. In her own words: "Je parle de lorsque je n'étais pas encore prise de cette façon et j'avais mes jambes, et pouvais me chercher un coin d'ombrage [...] ou un coin ensoleillé quand j'étais lasse de l'ombre comme toi, et ce sont tous de mots vides" (45). The legs, the corner in the shade, the corner in the sun are all equally decontextualized: they are not a part of Winnie's present anymore, therefore they do not have any referential value since time itself - the notion of past, present and future - is insignificant.

It is clear that although the play continues to experiment with ways of theatrical expression that go beyond mimesis and question the traditional coordinates of time and space as well as the notion of logos as the center of all truths, it cannot escape the aporia which is inherent to language and representation themselves. As Patice Pavis observes in his study on theater semiotics, "text and stage operate on different levels: one is based on a linguistic system of arbitrary signs, the other is founded on iconic signs which present a figurative form of that reality of which they are signs" (150). In both cases, the sign is an essential unit of meaning that cannot be annulled. He also adds that avant-garde theater (including Beckett) shows a fundamental distrust towards the sign and tries to free itself from it "but always succumbs to it in the end" (182). While the play calls the body and its possibility to signify into question and shows dysfunctional language mechanisms, it cannot eliminate the two very elements which are at the essence of performance itself. Text and stage both rely on the sign for communication: it can be broken down, hidden, rewritten but it will continue to signify. In Winnie's case, the disappearance of her body does not lead to the impossibility for this hidden body to convey meaning. Simply, rather than communicating by presence it will talk by absence. Similarly, language which is elliptic, broken, without a context cannot be eliminated; in fact, it replaces the visual element when the latter fails. Since the spectator cannot see Winnie's legs or breasts, she talks about them in order to bring them back to a presence.

Oh les beaux jours makes language, Winnie's speech, the center of the play while at the same time rejecting the notion of logocentrism. The word, its ability to signify is called into question just as the body is. As Derrida states when talking about language and language production 
before he proceeds to deconstruct it, "reading and writing, the production or interpretation of signs, the text in general as fabric of signs [...] are preceded by a truth, or a meaning already constituted by and within the element of the logos" (14). In the play, the concept of essence, truth, origin, transcendence is but a signifier whose signified had been lost or misplaced. One of the most obvious examples can be found in Winnie's prayer at the opening of act one. She is said to be praying an inaudible prayer and no one knows exactly what she is saying. And it could not have been otherwise. Since there is no God, the very act of praying is but an empty gesture which is all form and no meaning. Winnie enacts the ritual of prayer by going through all the necessary motions, as described in the stage directions: "Elle joint les mains, les lève devant sa poitrine, ferme les yeux. Une prière inaudible" (12). The only words that are heard mark the end of this inaudible prayer ("Jesus-Christ Amen"). The text however remains a void unfilled but necessary in the economy of the play and of Winnie's day which apparently always starts out with the same ritualistic act. Therefore, the very word "prière," like other words in the play such as those referring to Winnie's hidden limbs, has no immediate correspondence with reality, no referential value that can be attached to it. In spite of that, it needs to be said as part of Winnie's own strategy to render the world "meaningful" to herself through words.

Winnie's affirmation of her own identity and of her femininity through her gestures, when possible, as well as through language, suggests an inner belief on her part that life is not worthless and that in spite of a lack of logic and meaning in her world, she is not ready to be buried and disappear. Even when hope seems lost and she is indeed buried up to the neck in the ground, Winnie is "plus que jamais attachée à defendre sa propre survie" (Streheler 215). While the world around her seems to be approaching its end, she certainly does not want to accept her fate and fights every morning to repeat those same gestures and rituals that let her know she is still alive and she is still not completely alone, as long as Willie remains by her side and she has an audience to perform for. Again her strength and her refusal to give up clash with a traditional cultural construct which sees the wife as the weak element of the couple. Not only does Winnie fight for her own survival, she also fights in order to keep her partner alive and at her side. The husband, Willie, on the other hand does nothing of the sort: he lets the day pass by him and, like many Beckettian characters, awaits the end without ever trying to help Winnie in her endeavors. 
As I have tried to demonstrate, Oh les beaux jours deals with some gender specific issues which would not have had the same result had the protagonist been a male. The power of the play comes from the complex dynamics of the husband and wife relations and by the fact that the traditional roles of husband and wife are reversed. In particular, Winnie is Beckett's first theatrical female character who discusses her sexuality, her desires and the need to keep them alive for as long as possible, if not through actions at least through language. As the play progresses, Winnie becomes increasingly aware of the need to hold on to her femininity as a way to cope with her shifting self. During the second act, since only her head is left out of the mound, Winnie cannot perform those typically feminine gestures of the first act which helped reinforce her identity as a good-looking woman. Her hands are not free anymore so she cannot reach for the feathered hat, file her nails or look at herself in the mirror. Therefore, Winnie cannot rely on external accessories to keep establishing her "self" - she must work with what she has left: words. As the marks of her sexuality disappear from view and are buried into the ground, she feels the need to talk about them, to name different parts of her body in order to keep them from disappearing in the ground and being forgotten forever. In the end, her sense of self is not lost precisely thanks to her language which even under the most adverse circumstances always succeeds in replacing the void left by her husband's silence and by the disappearance of her own body. While her actions cannot keep perpetuating the female stereotype she incarnates, her words can certainly do so. For this reason she will keep talking regardless of her husband's silence and she will continue to create meaning in a meaningless world where body and language seem to have no purpose and where there is no possibility to generate new life. 


\section{Notes}

1. There is the exception of Maddy Rooney in Tous ceux qui tombent. The play however, was written for the radio, not the stage and it is a "choral" play where many voices interact, Maddy Rooney being the most prominent one.

2. The only female protagonist who preceded Winnie is, again, Maddy Rooney who fits the more traditional role of mother and who obsesses throughout the play about sterility and childlessness which she sees as a curse.

3. Cf Fin de partie. Hamm: "Ici nous sommes dans un trou" (56); "Mon petit, dit-il comme si le sexe avait de l'importance. D'où sortait il? Il me nomma le trou" (72). 